Available online at http://journal.ugm.ac.id/ifnp DOI:

http://doi.org/10.22146/ifnp.33729

INDONESIAN FOOD AND NUTRITION PROCRESS

\title{
Study of Physical, Chemical, and Sensory Characteristics of Modified Square Banana Flour (Musa balbisiana)
}

\author{
Muhammad Nur Buwono ${ }^{1)}$, Bambang Sigit Amanto ${ }^{1)^{*}}$, and Esti Widowati ${ }^{1)}$ \\ 1)Department of Food Science and Technology, Universitas Sebelas Maret Surakarta \\ JI. Ir Sutami 36A Kentingan, Surakarta 57126, Central Java, Indonesia \\ *Corresponding author's email: amantobambang@yahoo.co.id
}

Received 6 March 2018; Accepted 28 June 2018; Published Online 30 June 2018

\begin{abstract}
Amylose content related to the glycemic index, the higher the content of amylose the lower the glycemic index thus good for diets. Starch modification through fermentation using lactic acid bacteria can be used to increase amylose. In this experiment, modification of Square banana (Musa balbisiana) flour was conducted using Lactobacillus fermentum at certain concentration and fermentation time. This study used a Completely Randomized Factorial Designs (CRFD) with variation of fermentation time ( 24 hours, 48 hours, 72 hours) and concentration of bacteria starter $(0.125 \% ; 0.250 \% ; 0.375 \% \mathrm{v} / \mathrm{v})$ as the factor. Data were statistically analyzed using Two-Way ANOVA. The results showed that the variation of fermentation time and concentration of starter change physical, chemical, and sensory characteristic of the flour. Water absorption, protein content, and amylose content were increased. However whiteness index, swelling power, solubility, and moisture content were decreased. Pasting properties was change significantly after this modification process. Meanwhile, antioxidant activity and sensory characteristics did not significantly change. In conclusion, the characteristics of the modified flour offer opportunities for the development of square banana flour-based food products with high amylose which good for the diet.
\end{abstract}

Keywords: Amylose; fermentation time; Lactobacillus fermentum; square banana flour

\section{Introduction}

The importation of wheat flour in developing countries such as Indonesia is relatively high. One of the potential locally raw materials used for substituting the wheat is square banana. Square banana (Musa balbisiana) is one of wild banana since it has many seeds and diploid. Starch content of square banana is approximately $90 \%$, amylose and protein content of square banana starch are 22.2\% and 1.61\% (Gutierrez, 2007). Amylose are closely related with glicemic index. The lower glycemic index related to high amylose content (Frei, 2003).

Modification of flour processing is one alternative to increase amylose and protein content. Fermentation is one modification alternatives that may change the rheological and chemical properties (Kohajdova, 2007; Ezekiel, 2010; Haydersah, 2012; Jenie, 2012; Hur, 2014). Meanwhile, the protein content of the flour could increase due to increasing biomass during lactic acid bacteria fermentation (Ezekiel, 2010). 
Lactic acid bacteria fermentation have reported increase amylose and protein conternt (Haydersah, 2012; Yi, 2016). Modification method by fermentation also can change flour characteristics such as whiteness index, swelling power, solubility, water absorption, and antioxidant (Numfor, 1994; Obadina, 2013; Jayus, 2016). One of the lactic acid bacteria that can change flour characteristics and increase amylose content is Lactobacillus fermentum (Haydersah, 2012; $\mathrm{Yi}, 2016)$. In this experiments, a variation of fermentation time and starter concentration will be applied to square banana flour.

In order to identify the properties of square banana flour as an alternative of wheat flour subtitute, physics, chemical, and sensory atribute need to investigated. This study aim to understand the physics (whiteness index, swelling power, solubility, water absorption, and amylography), chemical (moisture content, protein content, and antioxidant activity), and sensory characteristics of square banana modified flour by variation of fermentation time and Lactobacillus fermentum starter concentration.

\section{Materials and Methods \\ Material and Inoculant Preparation}

Unripe square banana (Musa

balbisiana) was obtained from Bakung, Klaten, Central Java. Lactobacillus fermentum FNCC 0322 was obtained from Food and Nutrition Culture Collection, Inter-University Center, Universitas Gadjah Mada Yogyakarta. The strain was stored at $-80^{\circ} \mathrm{C}$ in de Man Rogosa Sharpe (MRS) broth (Merck), containing 20\% (v/v) glycerol (de Man et al., 1960). Before experimental use, the bacteria were propagated consecutively in MRS broth at $37^{\circ} \mathrm{C}$ for $24 \mathrm{~h}$. Lactobacillus fermentum FNCC 0322 was grown in MRS broth at $37^{\circ} \mathrm{C}$ for $48 \mathrm{~h}$ until $10^{8}$ cell $/ \mathrm{mL}$ for starter inoculum.

\section{Square Banana Flour Production}

Square banana flour production with and without fermentation according to Nurdjanah (2011) and Jenie (2012) with some modification method. Square banana was peeled and sliced with thickness 3-5 $\mathrm{mm}$. The banana seed was included in the process. Sliced banana were submerged fermentation in $10^{8} \mathrm{cell} / \mathrm{mL}(0.125 \%, 0.25 \%$, and $0.375 \%$ $\mathrm{v} / \mathrm{v})$ Lactobacillus fermentum FNCC 0322 starter inoculum on each container with different fermentation time ( $24 \mathrm{~h}, 48 \mathrm{~h}$, and $72 \mathrm{~h}$ ). The sliced banana was dried at $50^{\circ} \mathrm{C}$ for $12 \mathrm{~h}$ then sieved 80 mesh. For the square banana flour control, the process was similar but without submerged fermentation.

\section{Analysis}

\section{Physical Properties Analysis \\ Whiteness Index}

Whiteness index assay was carried out using the method of Zarubica (2005). Chromameter (CL-200 Konica Minolta) was used to obtain $L, a, b$ of the sample. Whiteness index were calculated using the following equations:

$$
W_{(\text {Stensby) }}=L+3 a-3 b
$$

\section{Swelling Power}

Swelling Power was carried out using the method of Leach (1959). 0.1 gram samples and added with $10 \mathrm{ml}$ distilled water. Heated for 30 minute at $60^{\circ} \mathrm{C}$ then centrifuged at $2500 \mathrm{rpm}$ for 15 minute. The supernatant was carefully decanted. The precipitate with the centrifuge tube was weighed. Swelling power (Sp) was calculated by this following equation:

$$
\mathrm{Sp}=\frac{\text { weight of paste }(\mathrm{g})}{\text { weight of dry flour }(\mathrm{g})}
$$

\section{Solubility}

Solubility test was carried out using simple test method of Fardiaz (1992). Dried sample dilluted into $100 \mathrm{ml}$ distillated water. The mixture filtered with filter paper, then 
filter paper with residue were oven dried at $105^{\circ} \mathrm{C}$ for 3 hour. The dry filter paper and residue cooled in a desiccator for 15 minute.

Solubility (S) was calculated by this following equation:

$\mathrm{S}=1-\frac{(\mathrm{c}-\mathrm{b})}{\frac{100-\% \text { moisture content }}{100} \times \mathrm{a}} \times 100 \%$

Where $a$ is weight of dried sample, $b$ is weight of dried filter paper, and $c$ is weight of filter paper and residue.

\section{Water Absorption Capacity}

Water absorption capacity test was carried out using simple test method of Lidiasari (2006). $3 \mathrm{~g}$ dried sample placed on filter paper, poured with $13 \mathrm{~g}$ warm water $\left(40^{\circ} \mathrm{C}\right)$. Water that came out accommodated and then weighed

Water absorption capacity (\%) was measured by this following equation:

$$
\%=\frac{\mathrm{Iww}(\mathrm{g})-\mathrm{Dww}(\mathrm{g})}{\mathrm{ws}(\mathrm{g})} \times 100 \%
$$

where Iww is initial water weight, dww is discharge water weight and ws is weight of sample.

\section{Amylography Properties}

The amylography properties of starch was obtained from Rapid Visco Analyzer (RVA) method use viscometer (DV-II Pro, Brookfield). with $2.5 \mathrm{~g}$ dried sample dispersed in $25 \mathrm{ml}$ of distilled water. A heating and cooling cycle was programmed in the following manner; the sample was heated from 50 to $95^{\circ} \mathrm{C}$ for $\pm 30 \mathrm{~min}$, held at $95^{\circ} \mathrm{C}$ for $2 \mathrm{~min}$ and cooled to $50^{\circ} \mathrm{C}$ within $3 \mathrm{~min}$. The gelatinization parameters such as maximum gelatinization temperature, peak viscosity, holding strength, final viscosity, break down, and set back were determined.

\section{Chemical Properties Analysis \\ Proximate analysis}

The proximate analysis of native rice starch was performed according to the standard methods described in the AOAC (2005), i.e. moisture content and protein content. Protein content was estimated from nitrogen content by Kjeldahl method multiplied by 6.25 .

\section{Amylose Content}

Amylose content analysis was carried out using iodo colorimetry method of Juliano (1971). $100 \mathrm{mg}$ of sample were weighed into a $100 \mathrm{~mL}$ volumetric flask and mixed with $1 \mathrm{~mL}$ ethanol and $9 \mathrm{~mL}$ of $2 \mathrm{M} \mathrm{NaOH}$. The samples were diluted and the iodine solution was added. After $10 \mathrm{~min}$ incubation at room temperature, the absorbance at $620 \mathrm{~nm}$ was analyzed with a spectrophotometer and the amylose content was calculated based on the standard curve.

\section{Antioxidant Activity}

Antioxidant activity analysis was carried out using modified method of Molyneux (2004). $50 \mathrm{mg}$ sample was weighed into aluminum foil coated reaction tube and dilluted with $10 \mathrm{ml}$ metanol. The solution was vortex 1 minute then stand for 24 hours. $1 \mathrm{ml}$ of DPPH in methanol was added into $1 \mathrm{ml}$ solution then stand for 30 minute. The absorbance measurement is given as $516 \mathrm{~nm}$. Antioxidant activity (\%) was measured by this following equation:

$$
\%=\frac{\mathrm{CA}-\mathrm{SA}}{\mathrm{CA}} \times 100 \%
$$

where CA is control absorbance, and SA is sample absorbance.

\section{Sensory Properties Analysis}

Sensory properties analysis with preference test used 25 untrained sensory panels.

\section{Experimental Design}

Each procedure described above, was conducted three times. The study was conducted using a complete randomized design with two factors, including variation of 
fermentation length and starter inoculum concentration of Lactobacillus fermentum FNCC 0322, with two way analysis of variance (ANOVA) was performed to test the statistical significance of differences. ANOVA was followed by Duncan's multiple range test. The significance level was $P<0.05$ and the software used was SPSS 20 for windows.

\section{Results and Discussion}

Effect of fermentation time of square banana flour to whiteness index, swelling power, solubility, and water absorption as shown in Table 1, while the effect of starter concentration shown in Table 2. Whiteness index of square banana flour from variation of fermentation time and starter concentration of L. fermentum FNCC 0322 as shown in

Figure 1.

Table 1. Effect of Fermentation Time on Whiteness index, Swelling power, Solubility, and Water Absorption Capacity

\begin{tabular}{ccccc}
\hline $\begin{array}{c}\text { Fermentation Time } \\
\text { (Hour) }\end{array}$ & Whiteness index & $\begin{array}{c}\text { Swelling power } \\
(\mathrm{g} / \mathrm{g})\end{array}$ & Solubility (\%) & $\begin{array}{c}\text { Water Absorption } \\
\text { Capacity }(\mathrm{g} / \mathrm{g})\end{array}$ \\
\hline $\begin{array}{c}\text { Control } \\
24\end{array}$ & $58.19^{\mathrm{b}} \pm 1.97$ & $6.84^{\mathrm{c}} \pm 0.41$ & $23.51^{\mathrm{b}} \pm 2.34$ & $2.11^{\mathrm{a}} \pm 0.11$ \\
48 & $52.34^{\mathrm{a}} \pm 3.77$ & $6.22^{\mathrm{b}} \pm 0.97$ & $19.86^{\mathrm{a}} \pm 1.94$ & $2.45^{\mathrm{ab}} \pm 0.34$ \\
72 & $54.12^{\mathrm{a}} \pm 3.08$ & $5.96^{\mathrm{ab}} \pm 0.68$ & $18.56^{\mathrm{a}} \pm 1.31$ & $2.45^{\mathrm{ab}} \pm 0.27$ \\
\hline
\end{tabular}

Mean value \pm standard deviation. Means within a column sharing followed by the same letters do not differ statistically from each other $(P<0.05)$.

\section{Whiteness Index}

Whiteness index of square banana flour is in Figure 1 and Table 1. Based on the results, square banana flour modified with fermentation show whiteness index lower than the square banana flour control. The same result showed in Table $\mathbf{2}$, since variation of starter inoculum concentration gave whiteness index lower than square banana flour control. From the result, it can be shown that modification with fermentation can decrease whiteness index of square banana flour. In accordance with its low whiteness index, fermentation then led to Maillard reaction occurance between reduction sugar and amino acid, which resulted from Lactobacillus fermentum proteolytic activity (El-Ghaish, 2010; Fossi, 2013). The small particle from seed was also caused the formation of dark color on square banana flour. Therefore, the longer the fermentation and the higher starter concentration shown whiteness index increased. It can be assumed longer fermentation time and higher starter concentration produce more organic acid. In line with Anyasi (2017) that pretreatment with organic acid reducing browning of unripe banana flour.

Table 2. Effect of Starter Concentration on Whiteness index, Swelling power, Solubility and Water Absorption Capacity

\begin{tabular}{ccccc}
\hline $\begin{array}{c}\text { Starter } \\
\text { Concentration (\%) }\end{array}$ & Whiteness index & $\begin{array}{c}\text { Swelling power } \\
(\mathrm{g} / \mathrm{g})\end{array}$ & Solubility (\%) & $\begin{array}{c}\text { Water Absorption } \\
\text { Capacity (g/g) }\end{array}$ \\
\hline Control & $58.19^{\mathrm{c}} \pm 1.97$ & $6.84^{\mathrm{c}} \pm 0.41$ & $23.51^{\mathrm{c}} \pm 2.34$ & $2.11^{\mathrm{a}} \pm 0.11$ \\
0.125 & $53.91^{\mathrm{ab}} \pm 1.78$ & $6.66^{\mathrm{c}} \pm 0.61$ & $19.65^{\mathrm{b}} \pm 1.88$ & $2.45^{\mathrm{ab}} \pm 0.36$ \\
0.250 & $50.92^{\mathrm{a}} \pm 3.58$ & $6.02^{\mathrm{b}} \pm 0.43$ & $20.92^{\mathrm{b}} \pm 2.45$ & $2.58^{\mathrm{b}} \pm 0.31$ \\
0.375 & $56.21^{\mathrm{bc}} \pm 2.07$ & $5.19^{\mathrm{a}} \pm 0.26$ & $17.38^{\mathrm{a}} \pm 2.57$ & $2.43^{\mathrm{ab} \pm 0.22}$ \\
\hline
\end{tabular}

Mean value \pm standard k. Means within a column sharing followed by the same letters do not differ statistically

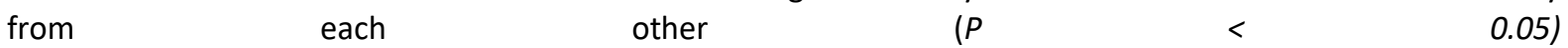


A

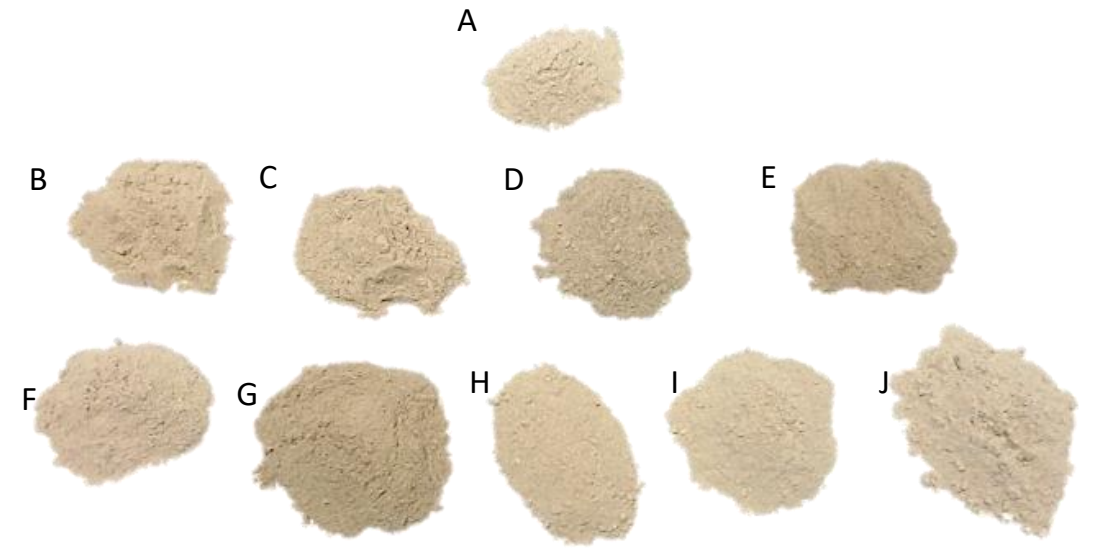

Figure 1. Whiteness index of square banana flour with variation of fermentation time and starter concentration of L. fermentum FNCC 0322: (A) Control, (B) 24 h; 0.125\%, (C) 48 h; 0,125\%, (D. 72 h; 0.125\%, (E) 24 h; 0.250\%, (F) 48 h; 0.250\%, (G) 72 h; 0.250\%, (H) 24 h; 0.375\%, (I) 48 h; 0.375\%, (J) 72 h; $0.375 \%$.

\section{Swelling Power}

According to Table $\mathbf{1}$ and Table 2, showed that fermentation time and starter inoculum concentration decreased swelling power. From the result, there is a correlation between longer fermentation time and higher starter concentration could be decreased swelling power. Among the effect of fermentation time and starter concentration, the drop in swelling power caused by enzyme and lactic acid from Lactobacillus fermentum which hydrolyzed the amorphous area of the starch granule (Sani, 2002; Santoyo, 2003; Fossi, 2011). The hydrolyzed process during fermentation caused less water uptake and decrease swelling power (Numfor, 1995).

There are many factor which influence swelling power, such as amylose, protein, lipid, phospor, and particle size (Aprianita, 2014). The results are line with Aprianita (2014) stated that amylose plays an important role in swelling power, which can strengthen the internal granule tissue and limit the ability to expand. As the result, there are correlation between swelling power was decreased while amylose content was increased (Table 5 and Table 6).

\section{Solubility}

The solubility of flour determined as the weight ratio of the soluble flour to the dry flour sample. Based on the results Table 1 and Table 2, solubility of square banana flour modified with fermentation was lower than control due to variation of fermentation time and starter concentration. According to Numfor (1995) stated that fermentation could be lowering solubility cause of during the fermentation process resulted metabolite which could change $\mathrm{C}, \mathrm{H}$, and $\mathrm{O}$ bonds of starch granule, there is possible intermolecular hydrogen-bonding of fragments, resulting in a reduction of the free hydroxy $(\mathrm{OH})$ groups. Thus, the fragments could realign and form new hydrogen bonds, resulting in greater internal granule stability which reduced solubility (Numfor,1995).

\section{Water Absorption Capacity}

Water absorption indicates the ability of raw materials to absorb water and is associated with the amount of starch in a material. Based on results from Table 1 and Table 2, showed the increase of water absorption on fermented modification square banana flour. From these results, it can be 
assumed that fermentation of Lactobacillus fermentum produce ethanol which could make the surface tension decreased and replaced the water position during the fermentation process so that when square banana slice dried the process was more quickly dry. As these results loses of water, cause increased the hydrophilic properties in flour. From these results, it can be inferred that fermentation was influenced increasing of water absorption capasity of square banana flour. Effect of fermentation time on amylography properties square banana flour as shown in Table 3, while the effect of starter concentration on amylography properties as shown in Table 4. Based on the results, there were significant change in pasting temperature, pasting time, peak viscosity, cold paste viscosity, and setback on square banana flour with pretreated fermentation.

Table 3. Effect of Fermentation Time on Amylography Properties Square Banana Flour

\begin{tabular}{|c|c|c|c|c|c|c|}
\hline \multirow{2}{*}{$\begin{array}{l}\text { Fermentation } \\
\text { Time (Hour) }\end{array}$} & \multicolumn{2}{|c|}{ Gelatinization } & \multicolumn{3}{|c|}{ Peak Viscosity (cP) } & \multirow[b]{2}{*}{$\begin{array}{l}\text { Setback } \\
\text { (cP) }\end{array}$} \\
\hline & $\begin{array}{c}\text { Temperature } \\
\left({ }^{\circ} \mathrm{C}\right)\end{array}$ & $\begin{array}{c}\text { Time } \\
\text { (menit) }\end{array}$ & $\begin{array}{c}\text { Temperature } \\
\left({ }^{\circ} \mathrm{C}\right)\end{array}$ & $\begin{array}{c}\text { Time } \\
\text { (menit) }\end{array}$ & $\begin{array}{l}\text { Viscosity } \\
\text { (cP) }\end{array}$ & \\
\hline Control & $63.77^{a} \pm 17.01$ & $\begin{array}{c}10.00^{\mathrm{a}} \pm \\
4.36\end{array}$ & 80.70 & 14.50 & $\begin{array}{c}4,175.00 \pm \\
1,088.94\end{array}$ & $\begin{array}{l}2,196.67^{\mathrm{ab}} \\
\pm 918.59\end{array}$ \\
\hline 24 & $85.26^{b} \pm 3.72$ & $\begin{array}{c}15.89^{\mathrm{b}} \pm \\
0.60\end{array}$ & $\mathrm{Td}$ & $\mathrm{Td}$ & $\mathrm{Td}$ & $\begin{array}{l}2,687.78^{b} \pm \\
352.07\end{array}$ \\
\hline 48 & $86.30^{b} \pm 4.29$ & $\begin{array}{c}16.00^{\mathrm{b}} \pm \\
1.41\end{array}$ & $\mathrm{Td}$ & $\mathrm{Td}$ & $\mathrm{Td}$ & $\begin{array}{l}2,271.11^{\mathrm{ab}} \pm \\
746.81\end{array}$ \\
\hline 72 & $89.72^{b} \pm 4.29$ & $\begin{array}{c}18.78^{c} \pm \\
2.49\end{array}$ & $\mathrm{Td}$ & $\mathrm{Td}$ & $\mathrm{Td}$ & $\begin{array}{l}1,563.33^{\mathrm{a}} \pm \\
806.87\end{array}$ \\
\hline
\end{tabular}

\section{Amylography Properties}

Pasting temperature from square banana flour fermentation treatment showed a higher temperature than square banana flour control. Moreover, the pasting time from

required higher temperatures and longer time to be gelatinized (Noda et al., 2003). The results are in line increased the amylose content in Table 5 and Table 6 . Peak viscosity from control flour detected on $4175 \mathrm{cP} ; 80.70$ ${ }^{\circ} \mathrm{C}$; 14.50 minute. Meanwhile, peak viscosity of square banana flour with fermentation treatment can not be detected. This results correlated with amylose which could increased viscosity caused by amylose chain square banana flour with fermentation treatment took longer than control. Increased of pasting temperature and pasting time caused by changes in starch structure influenced by higher amylose content, which

tended more stronger than amylopectin chain so that required high temperature and longer time to achived the maximum viscosity (Chung, 2011).

The setback is the result of a reduction in peak viscosity with cold viscosity. Overall setback from square banana with fermentation treatment showed decreased along with fermentation time and starter concentration. 
Table 4. Effect of Starter Concentration on Amylography Properties Square Banana Flour

\begin{tabular}{|c|c|c|c|c|c|c|}
\hline \multirow{2}{*}{$\begin{array}{l}\text { Fermentation } \\
\text { Time (Hour) }\end{array}$} & \multicolumn{2}{|c|}{ Gelatinization } & \multicolumn{3}{|c|}{ Peak Viscosity (cP) } & \multirow{2}{*}{ Setback (cP) } \\
\hline & $\begin{array}{c}\text { Temperature } \\
\left({ }^{\circ} \mathrm{C}\right)\end{array}$ & $\begin{array}{c}\text { Time } \\
\text { (menit) }\end{array}$ & $\begin{array}{c}\text { Temperature } \\
\left({ }^{\circ} \mathrm{C}\right)\end{array}$ & $\begin{array}{c}\text { Time } \\
\text { (menit) }\end{array}$ & Viscosity (cP) & \\
\hline \multirow[t]{2}{*}{ Control } & $63.77^{a} \pm 17.01$ & $10.00^{\mathrm{a}} \pm$ & 80.70 & 14.50 & $4,175.00 \pm$ & $2,196.67^{a} \pm$ \\
\hline & & 4.36 & & & $1,088.94$ & 918.59 \\
\hline \multirow[t]{2}{*}{0.125} & $86.14^{b} \pm 3.90$ & $16.56^{\mathrm{b}} \pm$ & $\mathrm{Td}$ & $\mathrm{Td}$ & $\mathrm{Td}$ & $2,533.33^{\mathrm{a}} \pm$ \\
\hline & & 2.30 & & & & 942.16 \\
\hline \multirow[t]{2}{*}{0.250} & $86.64^{b} \pm 5.07$ & $16.89^{\mathrm{b}} \pm$ & $\mathrm{Td}$ & $\mathrm{Td}$ & $\mathrm{Td}$ & $2,014.44^{\mathrm{a}} \pm$ \\
\hline & & 2.47 & & & & 619.16 \\
\hline \multirow[t]{2}{*}{0.375} & $88.49^{b} \pm 3.36$ & $17.22^{\mathrm{b}} \pm$ & $\mathrm{Td}$ & $\mathrm{Td}$ & $\mathrm{Td}$ & $1,974.44^{\mathrm{a}} \pm$ \\
\hline & & 1.72 & & & & 755.04 \\
\hline
\end{tabular}

Mean value \pm standard deviation. Means within a column sharing followed by the same letters do not differ statistically from each other $(P<0.05)$.

According to Soh (2006) stated that these have correlated with increased of amylose content which made flour were more diffilcult to be gelatinized so that the retrogradation can also be avoided. Starchbased on its gelatinization profile there are 4 types namely type A, B, C and D (Collado, 2001). From Rapid Visco Analyzer result showed there was change on gelatinization profile from type $A$ on control flour into type $C$ on overall square banana flour with fermentation treatment (Figure 2).
A

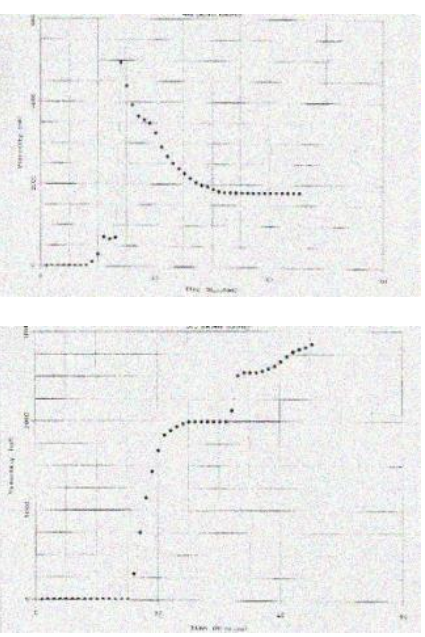

G

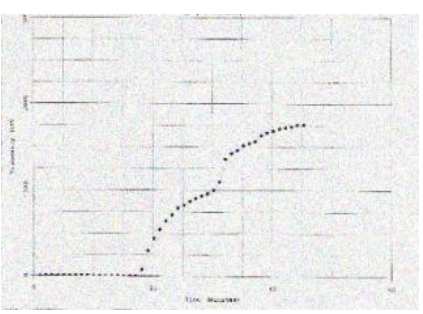

B

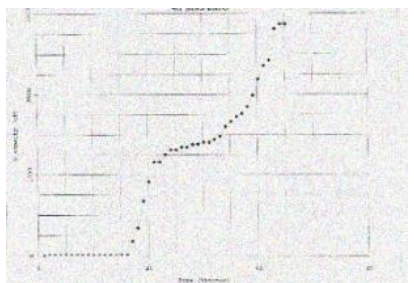

E

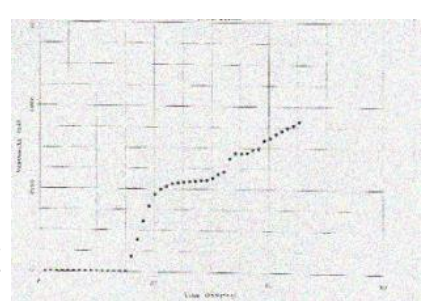

H

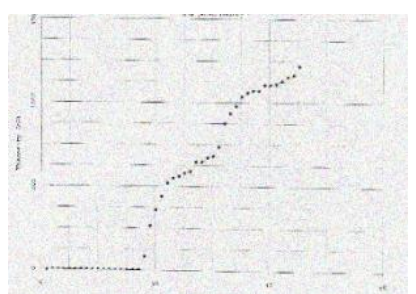

J
C

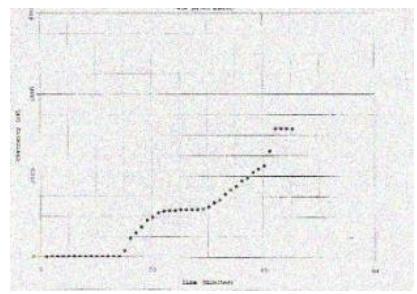

F
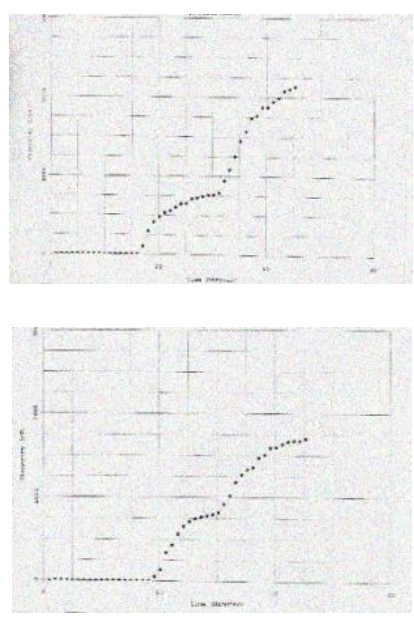
Figure 2. The pasting properties of Square Banana Flour with variation of fermentation time and starter concentration of L. fermentum FNCC 0322 : (A) Control, (B) 24 h; 0.125\%, (C) 48 h; 0,125\%, (D. 72 h; 0.125\%, (E) 24 h; 0.250\%, (F) 48 h; 0.250\%, (G) 72 h; 0.250\%, (H) 24 h; 0.375\%, (I) 48 h; 0.375\%, (J) 72 h; $0.375 \%$.

Gelatinization profile starch type $C$ has shown in the absence of maximum viscosity and shows high heat resistance with restricted swelling starches. Starch with type C gelatinization profile can be used for processed extrusion food products such as noodles.

\section{Chemical Properties of Square Banana Flour}

Effect of fermentation time of square banana flour to moisture content, protein content, amylose content and antioxidant activity as shown in Table 4, while the effect of starter concentration shown in Table 5.

\section{Moisture Content}

Moisture content from square banana with fermentation treatment and control presented in Table 5 and Table 6. Based on the result there was significantly effect from fermentation process due to fluctuating result on moisture content. According to Yenrina (2015) stated that the small water binding capacity when drying process could be affect the moisture content. Furthermore, it can be assumed that the increased in fermentation time $72 \mathrm{~h}$ and starter concentration $0.375 \%$ caused by more water which absorbed into banana sliced during fermentation process.

Table 5. Effect of Fermentation Time on Chemical Properties of Square Banana Flour

\begin{tabular}{ccccc}
\hline $\begin{array}{c}\text { Fermentation Time } \\
\text { (Hour) }\end{array}$ & $\begin{array}{c}\text { Moisture Content } \\
(\%)\end{array}$ & $\begin{array}{c}\text { Protein Content } \\
(\%)\end{array}$ & $\begin{array}{c}\text { Amylose } \\
\text { Content } \\
(\% \mathrm{db})\end{array}$ & $\begin{array}{c}\text { Antioxidant Activity } \\
(\%)\end{array}$ \\
\hline Control & $10.16^{\mathrm{bc}} \pm 0.53$ & $3.94^{\mathrm{a}} \pm 0.77$ & $16.47^{\mathrm{a}} \pm 1.11$ & $15.85^{\mathrm{b}} \pm 1.54$ \\
24 & $8.88^{\mathrm{a}} \pm 1.59$ & $5.05^{\mathrm{b}} \pm 0.62$ & $24.90^{\mathrm{b}} \pm 4.88$ & $14.80^{\mathrm{ab}} \pm 1.80$ \\
48 & $8.26^{\mathrm{a}} \pm 2.53$ & $5.66^{\mathrm{b}} \pm 0.96$ & $23.17^{\mathrm{b}} \pm 5.07$ & $13.85^{\mathrm{a}} \pm 2.05$ \\
72 & $10.84^{\mathrm{c}} \pm 3.35$ & $6.55^{\mathrm{c}} \pm 1.82$ & $29.36^{\mathrm{c}} \pm 4.31$ & $15.91^{\mathrm{b}} \pm 2.43$ \\
\hline
\end{tabular}

Mean value \pm standard deviation. Means within a column sharing followed by the same letters do not differ statistically from each other $(P<0.05)$

\section{Protein Content}

The protein content of square banana flour presented in Table 5 and Table $\mathbf{6}$. The result showed that fermentation treatment process affects increased on protein content. From Table 5 and Table 6, the highest protein content showed at fermentation time $48 \mathrm{~h}$ and starter concentration $0.250 \% \mathrm{v} / \mathrm{v}$. It can be assumed that increased of protein content caused by biomass from Lactobacillus fermentum containt peptidoglycan which increased and counted as increased of protein content.

Table 6. Effect of Starter Concentration on Chemical Properties of Square Banana Flour

\begin{tabular}{ccccc}
\hline $\begin{array}{c}\text { Starter Concentration } \\
(\%)\end{array}$ & $\begin{array}{c}\text { Moisture Content } \\
(\%)\end{array}$ & $\begin{array}{c}\text { Protein Content } \\
(\%)\end{array}$ & $\begin{array}{c}\text { Amylose } \\
\text { Content } \\
(\% \mathrm{db})\end{array}$ & $\begin{array}{c}\text { Antioxidant Activity } \\
(\%)\end{array}$ \\
\hline Control & $10.16^{\mathrm{b}} \pm 0.53$ & $3.94^{\mathrm{a}} \pm 0.77$ & $16.47^{\mathrm{a}} \pm 1.11$ & $15.85^{\mathrm{b}} \pm 1.54$ \\
$0.125 \%$ & $7.77^{\mathrm{a}} \pm 0.54$ & $5.38^{\mathrm{b}} \pm 0.53$ & $24.76^{\mathrm{c}} \pm 2.00$ & $15.67^{\mathrm{b}} \pm 0.86$ \\
$0.250 \%$ & $8.08^{\mathrm{a}} \pm 1.17$ & $6.93^{\mathrm{c}} \pm 1.60$ & $21.51^{\mathrm{b}} \pm 4.74$ & $13.22^{\mathrm{a}} \pm 1.83$ \\
$0.375 \%$ & $12.15^{\mathrm{c}} \pm 3.03$ & $4.95^{\mathrm{b}} \pm 0.79$ & $31.16^{\mathrm{d}} \pm 3.21$ & $15.67^{\mathrm{b}} \pm 2.05$ \\
\hline
\end{tabular}

Mean value \pm standard deviation. Means within a column sharing followed by the same letters do not differ statistically from each other $(P<0.05)$ 


\section{Amylose Content}

Table 5 and Table 6 showed amylose content from square banana flour with fermentation treatment increased the amylose content significantly. From the results, effect of fermentation time $72 \mathrm{~h}$ and starter concentration $0.375 \%$ give highest resulted in amylose content. Fermentation process could hydrolyze the starch, as the result it could increased amylose content (Numfor et al., 1994; Tavea et al., 2016). According to Mir et al.(2013) stated that high amylose content correlated with resistent starch and low glycemic index (GI). In addition, the high amylose content in foodstuffs has the potential to be used as raw material for instant food products such as noodles or extrusion products (Collado et al., 2001).

\section{Antioxidant Activity}

Antioxidant activity of square banana flour presented in Table 5 and Table 6 . Statistically there was no significant effect of fermentation process on square banana flour. Although in fermentation time $48 \mathrm{~h}$ and starter concentration $0.250 \%$ found that antioxidant activity was decreased. The decreased in antioxidant activity was previously reported by Hunaefi et al.(2013) which suggest that fermentation process causes a decreased in antioxidant activity due to enzymatic and non enzymatic degradation of phenol. In fermentation time $72 \mathrm{~h}$ and starter concentration $0,375 \%$, it was found that antioxidant activity was increased. It can be assumed that proteolytic by Lactobacillus fermentum influenced the increasing antioxidant activities. Rizello et al. (2017) reported fermentation increased antioxidant activity by releasing antioxidant peptides based on proteolytic activities.

\section{Sensory Properties of Square Banana Flour}

Based on Table 7 dan Table 8 showed that sensory properties include colour, aroma, texture, and overall. From the results of color content, highest color square banana flour control was showed on square banana flour control with preference 5,52. Color changed of square banana caused by Maillard reaction while drying between reduction sugar and amino acid resulted from Lactobacillus fermentum proteolytic activity (El-Ghaish, 2010; Fossi, 2013). The small particle from seed was also cause the formation of dark color on square banana flour.

Table 7. Effect of Fermentation Time on Organoleptic Properties of Square Banana Flour

\begin{tabular}{ccccc}
\hline Treatment & Colour & Aroma & Texture & Overall \\
\hline Control & $5.52^{\mathrm{b}} \pm 1.09$ & $4.48^{\mathrm{c}} \pm 1.48$ & $5.32^{\mathrm{b}} \pm 1.03$ & $5.12^{\mathrm{b}} \pm 0.97$ \\
24 & $4.29^{\mathrm{a}} \pm 1.10$ & $3.79^{\mathrm{a}} \pm 1.19$ & $4.52^{\mathrm{a}} \pm 1.17$ & $4.24^{\mathrm{a}} \pm 0.93$ \\
48 & $5.24^{\mathrm{b}} \pm 1.04$ & $4.33^{\mathrm{bc}} \pm 1.22$ & $5.27^{\mathrm{b}} \pm 1.04$ & $5.07^{\mathrm{b}} \pm 0.84$ \\
72 & $4.11^{\mathrm{a}} \pm 1.52$ & $3.97^{\mathrm{ab}} \pm 1.27$ & $4.68^{\mathrm{a}} \pm 1.32$ & $4.24^{\mathrm{a}} \pm 1.15$
\end{tabular}

Mean value \pm standard deviation. Means within a column sharing followed by the same letters do not differ statistically from each other $(P<0.05)$. Note : $1=$ extremely dislike; $2=$ dislike; $3=$ somewhat dislike; $4=$ neutral; 5 = somewhat like; 6 = like; 7 = extremely like

The aroma can be used as an indicator of the occurrence of damage to the product. Fermentation time at $48 \mathrm{~h}$ give resulted highest between all of square banana flour with fermentation treatment, but the preference give no significantly effect to flour control. According to Santoyo et al. (2003) stated that fermentation of Lactobacillus fermentum produced ethanol and lactic acid. It can be assumed that ethanol and lactic acid could provided a distinctive aroma so that affected on panelist preference. 
Table 8. Effect of Starter Concentration on Organoleptic Properties of Square Banana Flour

\begin{tabular}{ccccc}
\hline Treatment & Colour & Aroma & Texture & Overall \\
\hline Control & $5.52^{\mathrm{c}} \pm 1.09$ & $4.48^{\mathrm{b}} \pm 1.48$ & $5.32^{\mathrm{b}} \pm 1.03$ & $5.12^{\mathrm{b}} \pm 0.97$ \\
$0.125 \%$ & $4.20^{\mathrm{a}} \pm 1.32$ & $3.93^{\mathrm{a}} \pm 1.12$ & $4.77^{\mathrm{a}} \pm 1.24$ & $4.37^{\mathrm{a}} \pm 1.05$ \\
$0.250 \%$ & $4.44^{\mathrm{a}} \pm 1.44$ & $4.12^{\mathrm{ab}} \pm 1.28$ & $4.93^{\mathrm{ab}} \pm 1.17$ & $4.51^{\mathrm{a}} \pm 1.03$ \\
$0.375 \%$ & $5.00^{\mathrm{b}} \pm 1.10$ & $4.04^{\mathrm{ab}} \pm 1.33$ & $4.76^{\mathrm{a}} \pm 1.26$ & $4.67^{\mathrm{a}} \pm 1.07$
\end{tabular}

Mean value \pm standard deviation. Means within a column sharing followed by the same letters do not differ statistically from each other $(P<0.05)$

Note : $1=$ extremely dislike; 2 = dislike; 3 = somewhat dislike; $4=$ neutral; 5 = somewhat like; $6=$ like; $7=$ extremely like

Based on the results that square banana flour with variation fermentation time $48 \mathrm{~h}$ and starter concentration $0.250 \%$, statistically showed no significant different with control. In line previous research done by Jayus et al.(2016), that fermentation could give smooth texture and porous flour. In overall parameter, showed that square banana flour control has the highest preference of panelist and it shown that fermentation treatment did not give significantly improvement of sensory properties.

\section{Conclusion}

Fermentation time and starter inoculum concentration of Lactobacillus fermentum FNCC 0322 gave significant change on physical and chemical characteristic such as swelling power, solubility, amylography properties, protein content, amylose content, and antioxidant activity of square banana flour. Amylography of square banana flour was change due to fermentation process. Variation of fermentation time and starter inoculum concentration were also change pasting properties into type $\mathrm{C}$ which can used as material for making noodles. Yet, the sensory properties (colour, aroma, texture, and overall) of square banana flour did not give significantly change.

\section{References}

AOAC, 2005. Official Methods of Analysis. Association of Official Analytical Chemists. Benjamin Franklin Station, Washington.

Anyasi, T.A., Jideani, A., Mchau, G., 2017. Effects of organic acid pretreatment on microstructure, functional and thermal properties of unripe banana flour. Journal of Food Measurement and Characterization: 99-110.

Aprianita, A., Vasiljevic, T., Bannikova, A., and Kasapis, S. 2014. Physicochemical Properties of Flours and Starches Derived from Traditional Indonesian Tubers and Roots. Journal Food Science Technology 2014 Vol. 51(12): 36693679.

Chung, H.J., Liu, Q., Lee, L., and Wei, D. 2011. Relationship Between The Structure, Physicochemical Properties And In Vitro Digestibility Of Rice Starches With Different Amylose Contents. Food Hydrocolloids 25 (2011): 968-975.

Collado, L.S., L.B. Mabesa, C.G. Oates and H. Corke. 2001. Bihon-type of Noodles from Heat Moisture Treated Sweet Potato Starch. Journal Food Science, Vol.66 (4): 604-609.

El-Ghaish, S., Dalgalarrondo, M., Choiset, Y., Sitohy, M., Ivanova, I., Haertle, T., and Chobert, J.M. 2010. Characterization of 
A New Isolate of Lactobacillus fermentum IFO 3956 From Egyptian Ras Cheese With Proteolytic Activity. European Food Research and Technology 230: 635-643.

Ezekiel, O.O., Aworh, O.C., Blaschek, H.P., and Ezeji, T.C. 2010. Protein Enrichment of Cassava Peel by Submerged Fermentation with Trichoderma viride (ATCC 36316). African Journal of Biotechnology Vol. 9 (2):187-194.

Fardiaz, D., Nuri Andarwulan, Hanny Wijaya and Ni Luh Puspitasari. 1992. Petunjuk Praktikum Teknik Analisa Sifat Kimia dan Fungsional Komponen Pangan. Institut Pertanian Bogor Press. Bogor.

Fossi B.T., Tavea F., Jiwoua C., and Ndjouenkeu R. 2011. Simultaneous Production of Raw Starch Degrading Highly Thermostable $\alpha$-Amylase and Lactic Acid by Lactobacillus fermentum 04BBA19 in Fermentation for Simultaneous Production of Thermostable $\alpha$-Amylase and Lactic Acid. African Journal Of Biotechnology 10(34):6564-6574.

Frei, M., Siddhuraju,P., and Becker K. 2003. Studies On The In Vitro Starch Digestibility And The Glycemic Index Of Six Different Indigenous Rice Cultivars From The Philippines. Food Chemistry 83 (2003): 395-402.

Gutierrez, L.T., Uco, J.G.T., Guerrero, L.A.C., and Ancona, D.B. 2007. Isolation and Structure Investigations of Square Banana (Musa balbisiana) Starch. Starch/Stärke 59: 326-333

Haydersah J., Chevallier, I., Rochette, I., Mouquet-Rivier, C., Picq, C., MarrianePepin, T., Icard-Verniere, C., and PierreGuyot, J. 2012. Fermentation by Amylolytic Lactic Acid Bacteria and Consequences for Starch Digestibility of Plantain, Breadfruit, and Sweet Potato
Flours. Journal of Food Science Vol. 77(8): 466-471.

Hunaefi, D., Riedel, H., Akumo, D.N., Gruda,N., and Smetanska, I. 2013. Effect of Lactic Acid Bacteria Fermentation on Rosmarinic Acid and Antioxidant Properties of in vitro Shoot Culture of Orthosiphon aristatus as a Model Study. Food Biotechnology 27:152-177.

Igbabul, B.D., Bello, F.A., and Ani, E.C. 2014. Effect of fermentation on the proximate composition and functional properties of defatted coconut (Cocos nucifera L.) flour. Sky Journal of Food Science Vol. 3(5): $34-40$.

Jayus, Setiawan D., and Giyarto. 2016. Physical and Chemical Characteristics of Jackfruit (Artocarpus heterophyllus Lamk.) Seeds Flour Produced Under Fermentation Process by Lactobacillus plantarum. Agriculture and Agricultural Science Procedia 9 ( 2016 ): 342 - 347.

Jenie, B.S.L., Putra R.P., and Kusnandar F. 2012. Fermentasi Kultur Campuran Bakteri Asam Laktat dan Pemanasan Otoklaf Dalam Meningkatkan Kadar Pati Resisten dan Sifat Fungsional Tepung Pisang Tanduk (Musa paradisiaca Formatypica). Jurnal Pasca Panen 9 (1) : 18-26.

Juliano, B.O.A. 1971. Simplified assay for milled-rice amylose. Cereal Science Today 16: 334-340, 360.

Kohajdova, Z. and Karovicova,J. 2007. Fermentation Of Cereals For Specific Purpose. Journal of Food and Nutrition Research Vol.46(2): 51-57.

Leach, H.W., Mc Cowen, L.D., and Schoch T.J. 1959. Structure of The Starch Granules. In: Swelling and Solubility Patterns of Various Starches. Cereal Chemistry 36: 534-544.

Lidiasari, S., Merynda, I.S., and Syaiful, F. 2006. Pengaruh Perbedaan Suhu Pengeringan Tepung Tapai Ubi Kayu 
Terhadap Mutu Fisik Dan Kimia Yang Dihasilkan. Jurnal Ilmu-IImu Pertanian Indonesia Vol. 8(2):141 - 146.

Mir, J.A., Srikaeo,K., and Garcia, J. 2013. Effects Of Amylose And Resistant Starch On Starch Digestibility Of Rice Flours And Starches. International Food Research Journal 20(3): 1329-1335.

Molyneux, P. 2004. The Use of The Stable Free Radical Diphenylpicrylhydrazyl (DPPH) For Estimating Antioxidant Activity. Songklanakarin Journal Science Technology 26(2) : 211-219.

Noda, T., Nishiba, Y., Sato, T., and Suda, I. 2003. Properties of Starches from Several Low-Amylose Rice Cultivars. Cereal Chemistry 80(2):193-197.

Numfor, F.A., Walter Jr, W.M., and Schwartz, S.J. 1995. Physicochemical Change in Cassaa Starch and Flour Associated with Fermentation: Effect on Textural Properties. Starch/Starke 47(3): 86-91.

Nurdjanah, S., Musita, N., and Indriani,D. 2011. Karakteristik Biskuit Coklat Dari Campuran Tepung Pisang Batu (Musa Balbisiana Colla) dan Tepung Terigu pada Berbagai Tingkat Substitusi. Jurnal Teknologi dan Industri Hasil Pertanian Vol.16(1).

Nurhayati, Jenie B.S.L., Widowati S., and Kusumaningrum H.D., 2014. Komposisi Kimia dan Kristalinitas Tepung Pisang Termodifikasi Secara Fermentasi Spontan dan Siklus Pemanasan Bertekanan-Pendinginan. AGRITECH Vol. 34 (2): 146-150.

Obadina, A.O., Fegha, G.D., and Olugbile, A.O. 2013. Effect of Fermentation Periods on Chemical and Physicochemical Properties of Cocoyam Starch. Starch/ stärke 65: 747-752.

Sani A.I., Guyot J.M., and Guyot J.P. 2002. New Efficient Amylase-Producing Strains of Lactobacillus plantarum and L. fermentum Isolated From Different
Nigerian Traditional Fermented Foods. International Journal of Food Microbiology 72 (2002): 53-62.

Santoyo, MC., Loiseau, G., Sanoja, RR., and Guyot, JP. 2003. Study of starch fermentation at low $\mathrm{pH}$ by Lactobacillus fermentum Ogi E1 reveals uncoupling between growth and a-amylase production at $\mathrm{pH}$ 4.0. International Journal of Food Microbiology 80: 77 87.

Rizello, C.G., Lorusso, A., Russo, V., Pinto, D., Marzani, B., and Gobbetti, M. 2017. Improving the antioxidant properties of quinoa flour through fermentation with selected autochthonous lactic acid bacteria. International Journal of Food Microbiology 241: 252-261.

Soh, H.N., Sissons, M.J., and Turner, M.A. 2006. Effect of Starch Granule Size Distribution and Elevated Amylose Content on Durum Dough Rheology and Spaghetti Cooking Quality. Cereal Chemistry 83(5): 513-519.

Tavea, F., Fossi, B.T., Takop, N.G., and Njouenkeu, R. 2016. Extracellular Highly Thermostable $\alpha$-Amylase from a Strain of Lactobacillus fermentum: Production and Partial Characterization. Journal of Microbiology Research 2016 Vol. 6 (3): 47-54.

Yenrina, R., Azima, F., and Saputra, A. 2015. Chemical and Microbiological Properties of Mogaf (Modify Garut Flour) from Arrowroot Tuber (Maranta Arundinaceae L.) Fermented Spontaneously with Different Time. American International Journal of Contemporary Research Vol.5(2): 104109.

Yi,C. Yang, Y., Zhou, S., and He, Y. 2016. Role of Lactic Acid Bacteria in the Eating Qualities of Fermented Rice Noodles. Cereal Chemistry 072016. 
Zarubica, A.R., Miljkovic, M.N., Purenovic, M.M., and Tomic, V.B., 2005. Colour Parameters, Whiteness Indices and Physical Features Of Marking Paints for Horizontal Signalization. Facta Universitatis Series: Physics, Chemistry and Technology Vol. 3(2): 205-216. 